\title{
Constructing a Research-Based Program to Improve Primary School Students' Reading Comprehension Skills
}

\author{
Tuula Merisuo-Storm, Marjaana Soininen \\ University of Turku, Finland
}

\begin{abstract}
The first goal of the study reported in this article was to measure how well sixth graders understand newspaper text and whether they are able to derive the meanings of certain words in it from the context. For this purpose, the comprehension skills of 619 Finnish sixth-grade-students (aged 12-13 years) were measured. They read a newspaper article about shipwrecks in the Baltic Sea. They then answered 10 questions based on the article and explained the meaning of 10 underlined words in that article. The students' scores for answering the questions were, on average, significantly better than their scores for explaining the words. However, those students who performed poorly usually performed poorly at both tasks: 90 per cent of the students who gave only 0-4 correct answers to the comprehension questions only explained 0-4 words correctly.

The second goal was to design a program based on research literature and the test results. The objective was to generate teaching materials and practices that would help students to: 1) understand various kinds of texts from different genres; 2) learn to derive the meaning of an unknown word from the context; and 3) learn how to explain the meaning of the unknown word.
\end{abstract}

\section{Introduction}

According to the Finnish National Core Curriculum for Basic Education [1], every student should have an opportunity to acquire the knowledge and skills he or she will need in the future during his or her primary school years. For a child, language is an object as well as a tool of learning. Instruction should, therefore, systematically develop children's language-based study skills. Young students should acquire knowledge of language in increasingly demanding language-use situations. An essential part of instruction during the primary school years is learning reading comprehension strategies. Students' comprehension of diverse texts gradually improves as they become practiced in using these strategies and learn to utilise information from various sources.
Because there is a large selection of texts available the comprehension process is very complicated. Many young students have especial difficulty comprehending expository texts, which often have complex structures and include lots of new information. They sometimes contain abstract and logical relationships that are difficult to understand. In order to become skilful readers children should be given opportunities to read texts from different genres during their first years of school. As the different text structures will then become gradually familiar to them this will help them to comprehend more complex texts and issues in future. [2; 3]

Children should also learn to decide which comprehension strategies are the best in diverse reading situations, such as previewing, activating prior knowledge, predicting, monitoring, organising, summarising, questioning, making connections, and visualising. Comprehension strategies are necessary because they provide access to knowledge that is beyond a young reader's experience and help him or her to become a meta-cognitive reader. In addition, it is important for children to learn to monitor their own reading comprehension, detect unfamiliar words from the text, and try to find out what they mean. [4]

Students need good literacy skills if they are to be able to acquire new information. Students who do not understand what they are reading have problems studying almost any subject. Therefore, we thought it was important to find out if students reach the National Core Curriculum goals during the primary school years. The first goal of the study reported in this article was to find out how well students have learned to comprehend newspaper text and derive the meanings of the words it includes from the context during the first six school years. The second, and the most important, goal was to construct an intervention program that would effectively improve students' reading comprehension skills.

We considered newspaper articles to be good texts to use in the reading comprehension test because newspapers are an elemental part of everyday life for most Finnish people. In 2008, almost $90 \%$ of Finnish families had subscribed to at least one newspaper. In PISA (the OECD Program 
for International Student Assessment), it was found that $59 \%$ of 15 -year-old students read newspapers several times a week and $26 \%$ read newspapers several times a month. However, $15 \%$ of this age group only read newspapers, at most, once a month, and $2 \%$ not at all. [5] It is also important to motivate students to read newspapers because actively reading newspapers was related to good student reading skills in PISA. The students who read newspapers seldom or never proved to have poor reading skills [5]. Teachers should therefore make frequent use of newspapers. Newspaper articles provide a great variety of texts: news reports, articles on various themes, interviews, advertisements, columns, reviews, comments from readers, entertainment, comics, caricatures, weather reports, information about TV and radio programs, job advertisements, and so on. It is possible to create myriad exercises related to the versatile texts included in newspapers.

\section{The study}

A total of 619 students (287 boys and 332 girls) took part in the study at the end of their sixth year at school. Students studied in 22 schools in Western Finland and more than $90 \%$ of them had Finnish as a first language. Because the schools are comprehensive schools the students came from the full range of social backgrounds. The students read an article published in a local newspaper (Figure 1). The title of the article is 'Sea-archaeological sensation. Swedish scientists found a well-preserved Dutch ship from the 17th century in the bottom of the Baltic Sea' [6]. According to the article, many shipwrecks lie at the bottom of the Baltic Sea. They are well preserved because there are no shipworms in the Baltic Sea; in other seas shipworms destroy wooden ships.

\section{Meriarkzologinen sensaatio 1600 - upulta}

\section{Ruotsalaistutkijat löysivät Itämerestä lähes ehjänä säilyneen hollantilaisaluksen}

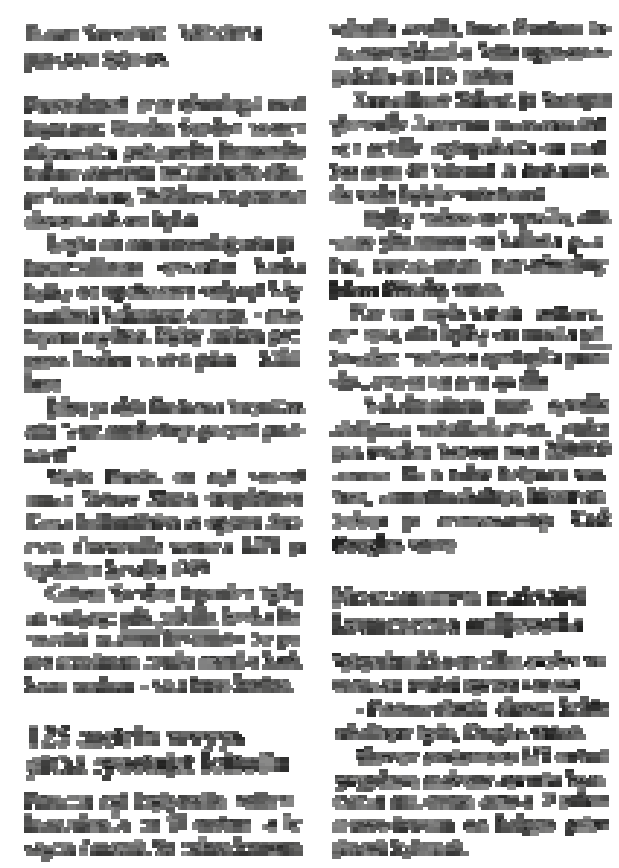

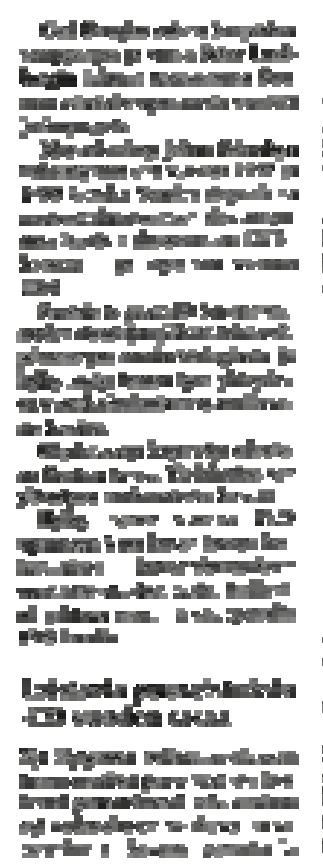

Figure 1. The article in the initial test

After reading the article, the students answered 10 questions about the article and explained the meanings of 10 words underlined in the article. The time for the task was not restricted, but most students were able to read the text, answer the questions, and explain the words during one school lesson (45 
minutes). In order to ensure that all the students' papers were scored using the same criteria all the answers to each question and all the explanations for each word that could be approved were listed for the markers.

It was easy to find answers to some of the questions in the text. For instance, 'Why isn't the ship lifted from the bottom of the sea?' and 'Why haven't robbers visited the shipwreck?' More than 90 per cent of the students answered correctly: 'It is too expensive' and 'The ship is so deep in the sea that they cannot get there'. The most difficult question was 'What is Vrow Maria?' Only 15 per cent of the students gave a correct answer. For instance, 'It is a ship that sunk in 1771 ' or 'It is a shipwreck' or 'It is the name of a ship'. It is surprising that this question proved to be so difficult because the answer can be found in the text. However, there are only two sentences at the beginning of the article that give information about Vrow Maria and the structure of the sentences is slightly complicated. The girls gave an acceptable answer significantly more often $(\mathrm{t}=$ 2.84, $\mathrm{p}=.005$ ) than the boys. Another difficult question proved to be 'Why are there so many Dutch shipwrecks in the Baltic Sea?' To be able to answer this question correctly a student had to be able to draw inferences from the text. The results show that 59 per cent of the students gave a correct answer that included one of the following ideas: 'Holland was a leading merchant and sea state in the 17th century' or 'There were a great number of Dutch ships sailing in the Baltic Sea' or 'They built a great number of ships in Holland'. However, several students answered incorrectly. For instance, 'The Dutch ships were so bad' or 'Because they sank'.

There is no significant difference between the boys' scores and the girls' scores in the question section. The percentage distribution of the students' total scores in the question section of the test is displayed in Figure 2.

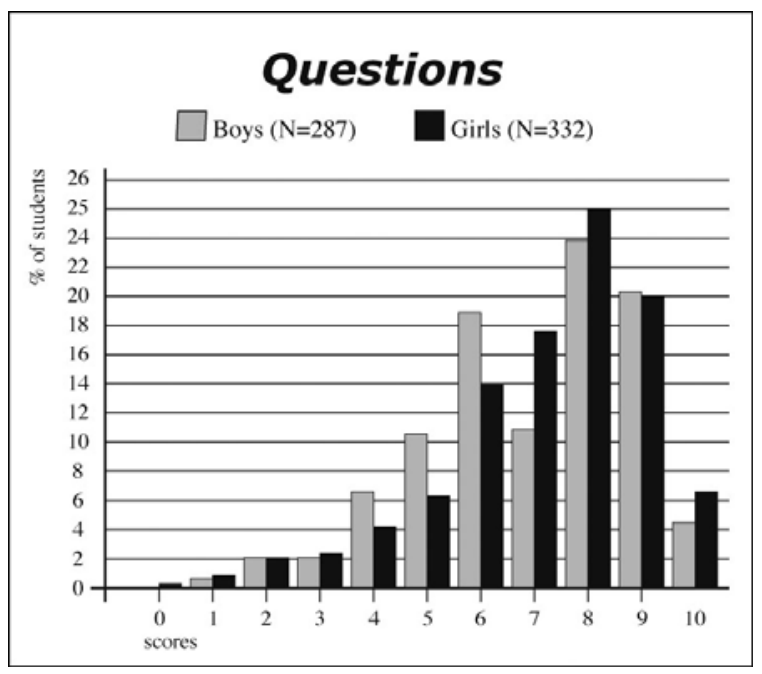

Figure 2. The percentage distribution of the boys' and the girls' total scores in the question section
Ten words in the article were underlined. The students' task was to explain what these words mean in this text. The most difficult concept to explain was ‘jalostettuja tuotteita’ [refined products]. Only 18 per cent of the students produced a correct explanation. The task was demanding because the context does not reveal the full meaning of the word although it does present some cues. The concept is found in the sentence: 'Textiles, salt, wine, and other refined products were imported into Finland'. The students had to compare the concept to the products mentioned in the beginning of the sentence and consider what they have in common. Similarly, the text does not give explicit cues about the meaning of the word 'sensaatio' [sensation], and only 42 per cent of the students gave a correct explanation. The word is in this sentence: 'This find is a sea-archaeological as well as a historical sensation, because it is so well preserved'.

Another difficult word was 'nelisensataa' [about four hundred]. Only 43 per cent of the students understood the slight difference between it and the word 'neljäsataa' [four hundred]. The easiest word was 'jatkossakin' [also in the future], and 80 per cent of the students explained it correctly. About 65 per cent of them could explain the concepts 'luottavainen' [trustful] and 'kuin liukuhihnalta' [as if from a conveyer belt] correctly. There was one word that the girls gave a correct explanation of significantly more often than the boys $(\mathrm{t}=3.42$, $\mathrm{p}=$ $.001)$ : about 57 per cent of the girls but only 43 per cent of the boys understood the word 'todennäköisesti' [evidently] in the sentence 'Swedish sea-archaeologists have found a 17thcentury shipwreck, which is evidently of Dutch origin, at the bottom of the Northern Baltic Sea'. The girls also succeeded better than the boys in explaining almost all the other words, and the difference between their aggregated scores is almost significant $(\mathrm{t}=2.23, \mathrm{p}=.026)$. The percentage distribution of the students' total scores in the word explaining section of the test is displayed in Figure 3. 


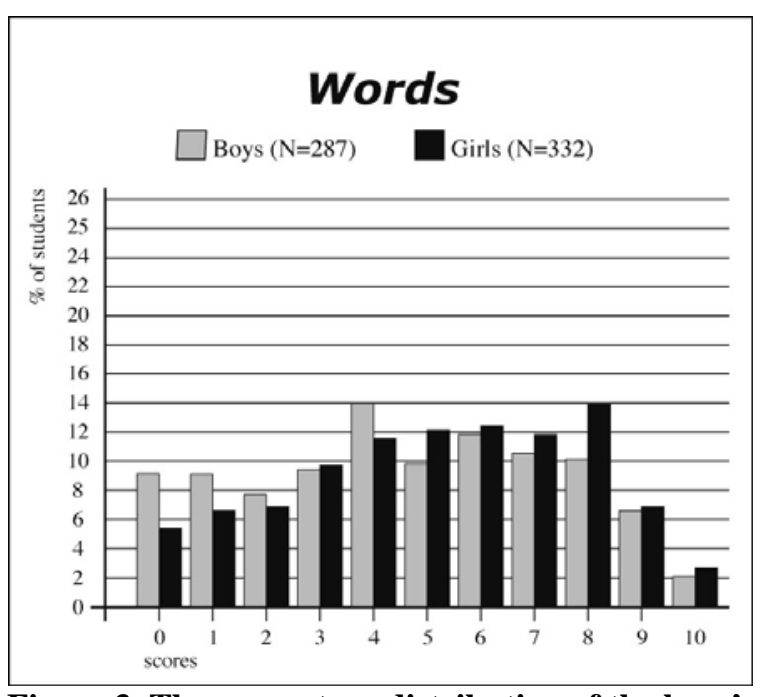

Figure 3. The percentage distribution of the boys' and the girls' total scores in the word explanation section

In both sections of the test the students' aggregated scores vary from 0 to 10 . The mean in the question section is $7.1(\mathrm{SD}=2.0)$ and in the word explaining section 4.9 (SD = 2.7). The difference between the students' scores for the two sections is significant $(\mathrm{t}=22.2, \mathrm{p}=.000)$. This may indicate that deriving the meaning of a word from a written context was a demanding new task for many students. However, there is a strong correlation between the students' success at explaining the words and their success at answering the questions ( $\mathrm{r}$ $=.50, \mathrm{p}=.000)$. Ninety per cent of the students who performed poorly when answering the questions (0-4 correct answers) had equally poor scores in the word section of the test. The test achieved a high degree of reliability, with a Cronbach's alpha (a measure of internal consistency) of .81.

\section{Constructing the intervention program}

The results of the test show that many sixthgraders had difficulties comprehending newspaper text and explaining the words in it. As a result, the goal was to generate teaching materials and practices that would help students to comprehend various kinds of texts and learn how to derive and explain the meanings of words from a written context. Another goal was to write texts that would motivate all students, especially boys, to read. Research has shown that the boys' attitudes towards reading are not as positive as girls' attitudes towards reading [7, 8]. The objective was to design a program based on research literature and the initial test results. The program consists of 10 learning sessions that last from 2 to 3 hours. At the beginning of each session the students read a text. After that they are set several exercises related to the text, which are performed as part of a small group.
The intervention program material also includes a teacher's guide, which provides information about the purpose of each exercise. There are also suggestions for additional activities. Teachers are asked to write down how each session was carried out, how much time was spent on each session, if the students did some of the exercises or read the texts at home, in what kind of groups the students worked, how the groups were constructed, which texts and exercises the students found most interesting, how the students' skills developed during the intervention period, and so on.

\subsection{Texts}

As readers, students are very different and they are motivated to read different texts. It is important for the reader to find the topic of the text interesting and possess enough prior knowledge about its subject matter to be able to understand it. It is therefore essential to offer students a wide range of reading material on diverse topics, with different levels of difficulty, and from different literary genres. Students may have special personal interests. Thus, to be able to motivate all students to read the teacher has to know what texts appeal to the individual students in his or her class. As was mentioned above, many boys are not motivated to read, and their reluctance to read leads to a decline in their reading skills. The latter, together with the consequent feeling of incompetence, can cause indifference towards reading. [7]

Teachers should consider whether it is possible to give poor readers a chance to improve their reading skills by reading texts that are not usually read at school. Guided by a skilful teacher, even reluctant readers may gradually learn to enjoy more sophisticated literature. It is often the case that boys who dislike literacy lessons in school still use reading for many purposes outside school and feel competent to read texts they have chosen for themselves. It seems probable that the difference between the two genders' reading attitudes and skills becomes even wider as the students get older. For this reason, consideration should be given to how young boys can be motivated both to read and to continue reading when they reach their teens. [8]

When children are able to read texts from various genres during their first years at school they become familiar with various kinds of text structures. This prepares them for comprehending more complex texts in the future. Young students often have more difficulty understanding information texts than narrative texts [2; 3]. However, the older they become the more often they need good reading comprehension skills in order to acquire new information. After reading a text they are expected to remember the most important ideas and concepts it contains. Nevertheless, many researchers have found 
that teachers seldom give their pupils opportunities to read expository texts during the first years of school [9].

Based on what is stated above, we considered it to be important to create a program that contains different kinds of texts. In order to make it easier for students to compare different texts and understand what features typify the different kinds of texts the program includes text groups that are related to the same themes. The first theme is bridges. Two texts are connected to London Bridge: the traditional story 'The Pedlar of Swaffham' and a non-fiction text about the colourful history of the bridge. The third text is a newspaper article about a bridge in Finland, which started to collapse one morning. The next three texts are connected to the second theme, stalactite caves: a non-fiction text about Carlsbad Caverns, a letter from a schoolboy at Carlsbad Caverns, and a non-fiction text about bats living in caves. There are also three texts related to the third theme, lifts: the life story of Elisha Otis (who invented a safe lift), a non-fiction text about lifts, and a non-fiction text about skyscrapers (because the invention of a safe lift made it possible to build high buildings). The fourth theme is flying dogs. The first text is a non-fiction text about dogs travelling in aeroplanes, the second is a newspaper article about an airline for dogs, and the third is a non-fiction text about Laika and other space dogs. In addition, some exercises involve students creating new texts on the original theme, but in a different genre.

\subsection{Exercises}

When When using the program the teachers are asked to give their students opportunities for cooperation, discussions, and teamwork during every session. As Thompson [9] points out, effective instruction provides opportunities for lively conversation and collaboration in constructing a shared understanding of the text. Teachers are also encouraged to model their own thinking process on think-alouds, and in this way provide an instructional scaffolding for comprehension.

According to Parker and Hurry [11], many teachers do not have explicit knowledge of reading comprehension strategies. It seems that direct oral questioning is the most frequently used strategy for teaching reading comprehension. However, this kind of directive questioning produces predictable correct answers and does not encourage students to develop more elaborate ideas. Comprehension instruction should give students the skills they will need later in life. A few minutes asking and answering questions about a text passage is not enough (even if the variety of questions is wide and appropriate the students' role is too passive). As a result, the exercises aim to teach the students several comprehension strategies. Before reading they call on their prior knowledge of the theme related to the text and skim read the text. They learn to pay attention to the pictures and titles related to the text as well as discuss what information they provide. The exercises also teach students to monitor their own reading comprehension and to choose appropriate comprehension strategies in various different contexts.

The most important activities during the sessions are students' small group discussions. In order to answer many of the questions about the texts students need to discuss them in groups so they can find reasons behind the events in a story, draw conclusions, and so on. It is easier in a group to put information from several idea units together [12], make inferences, and 'read between the lines' [11]. For instance, students discuss why the bridge in Finland that started to collapse one morning had won several prizes in spite of the trouble it had caused over the years. They compare the photos of the new bridge with photos of the old bridge and discuss why the old bridge was not solid enough. In addition, they discuss why so many people came to the old bridge's farewell party, and why the decision about demolishing the old bridge and building a new bridge were made so quickly in a town where these kinds of decisions usually take several years.

When doing the exercises the students learn how to locate the most significant information in a text and how to connect the information in different parts of the text. These kinds of activities also help them to learn to summarise a text, which is a very demanding task. In sixth grade many students continue to struggle with identifying the main ideas in a text and just repeat most of the text or give a very vague statement in their summary. Students gradually learn to understand that a good summary gives a complete picture of the text, only includes the important points (in same order as they appear in the text), and indicates how the different points are related. [13] For instance, in an exercise on Elisha Otis (the inventor of a safe lift) students choose the 5 most important pieces of information in the text from a list of 13 alternatives.

Research has shown that comprehension processes of various genres are different. The genre affects a reader's approach to the text, use of comprehension strategies, and how he or she makes inferences. It is possible that a reader who easily understands one type of text has difficulty understanding another type of text. This may suggest that comprehension instruction in one genre does not transfer to another genre. [14] Reading different genres and text formats during the intervention period produces opportunities for students to use different comprehension strategies and provides bases for discussion. Students compare different texts: fiction, non-fiction, newspaper texts, sportscoverage, text messages, emails, comics, websites, 
product descriptions, and so on. They learn to understand the typical features of different kinds of text as well as the genres of the texts. Diverse texts on the same theme provide good opportunities for this. For instance, when students discuss what kind of alterations they have to make when they write a newspaper article based on information in the schoolboy‘s letter from Carlsbad Caverns.

In addition, the exercises include several tasks that require the use of different information sources (e.g. books, maps, and the Internet). The students also create their own texts on the theme in different genres. The exercises also aim to advance students' critical reading skills; by analysing advertisements and the language used in them, for instance. Students discuss how the advertisements affect people. Using this knowledge they try to create advertisements that would, for example, show people living in old houses with no lifts how much easier their lives would be if they had modern lifts. They also create advertisements that aim to induce tourists to visit a stalactite cave.

During the initial test, students had much more difficulty explaining the words in the text than answering the questions about the article. The results suggest that deriving the meaning of an unknown word from the context was a new and demanding task for many pupils. The students are therefore taught strategies for deriving the meaning of a word from the context. They learn to locate cues in the text that help them to find out what the unknown words mean. It is important that they learn how to find the most productive context cues from the text. Their word meaning explanation skills improve when they learn to analyse texts in order to distinguish which cues provide the information that is needed. It is important that they also learn to evaluate whether the meaning of the word fits the context well enough. They may give an incorrect explanation of a word because they have chosen the wrong cues or not noticed the right cues. [15]

Cain [16] found that if students have an opportunity to explain the reasoning behind their own definitions or the correct definitions of words, then their ability to derive a word's meaning from its context in the text improves. When given a correct explanation, students who had arrived at their definition due to an incorrect explanation considered which cues in the text they had not noticed. Strategy instruction and feedback helped them to concentrate on what the text actually said. In addition, their reasoning skills as well as their skill at evaluating their own explanation improved. Tomesen and Aarnoutse [17] discovered that the students best learned to apply the strategies when they heard their teacher and peers think-aloud during the word explanation process. Therefore, in the teachers ${ }^{\text {* }}$ guide it is stressed that teachers should model their own thinking process on think-alouds.
When doing the initial test, many students did not understand that when trying to find out the meanings of words it is important to pay attention to the text context because words may have different meanings in different contexts [18]. For that reason, many exercises demonstrate that many words have other meanings, in addition to the one that first comes to mind. Several sentences in the exercises include the same word. However, the word has different meanings in each sentence and the students discuss what these meanings are. In order to assess whether they have understood the word correctly they may substitute the word with another word and check if the new word fits the context. Time is also spent learning to explain the words and analysing small differences in the meanings of two words that are almost the same.

For instance, students are asked to explain what the word 'jää' means in following sentences: Lepakko jää ilman ravintoa [The bat is left without food.]; Minä en jää tänne. [I do not stay here.]; Yksi kysymys jää vastaamatta [One question remains unanswered.] Pelkään, että jää sulaa liian aikaisin [I am afraid that the ice melts too early.] The word 'johtaa' has even more meanings: Ukkosenjohdatin johtaa salamaniskun maahan [The lightning conductor conducts the lightning to the ground.]; Irlannin joukkue johtaa kahdella maalilla. [The Irish team leads by two goals.] Presidentti johtaa maata. [The president leads the country]. There are also exercises that demonstrate how small differences in words can change their meaning: parantaa [make better, heal] and parantua [get better, get well]; nousta [get up, rise] and nostaa [lift, raise, draw (money from one's account)]; valita [choose, select] and valittaa [complain, groan, be sorry].

Several exercises also aim to broaden the students' vocabulary. This is especially important for students who are reluctant readers. Students who are eager readers encounter more words than those who read less. The eager readers also have many opportunities for acquiring and improving their vocabulary by drawing inferences from different contexts. There is evidence that vocabulary differences affect comprehension and that increasing vocabulary acquisition has a positive influence on reading comprehension $[18,19]$. Thus, for instance, when doing these exercises the students look for synonyms for given words within the texts. Students also discuss which words are used to express that something happens every day, every week, every year, twice a year, four times a year, and so on. They try to find opposites for given words and discuss which adjectives become their opposites if the prefix 'epä‘ [un] is added to them. For instance, this is the case with the adjectives onnistunut - epäonnistunut [successful - unsuccessful], varma - epävarma [certain - uncertain], and terveellinen epäterveellinen [healthy - unhealthy], but not with 
the adjectives tarpeellinen - tarpeeton [necessary unnecessary] and mahdollinen - mahdoton [possible -impossible].

\section{Conclusion}

One of the main goals of literacy teaching is to awaken children's interest in language and literature as well as give them a lasting positive attitude towards reading and writing [1]. Several studies have shown that schools have not been able to reach this goal, especially with regard to boys. However, with interesting reading material it is possible to encourage even the most reluctant students to read. It is therefore essential for teachers to use versatile reading materials in their classes [8]. They should also use a wide range of materials when teaching students to use comprehension strategies effectively in various contexts [14]. When the students become practiced in using the strategies their comprehension of diverse texts improves and they also learn to utilise information from various sources. These are skills they will need later in life [1].

The results of PISA show that actively reading newspapers is related to good reading skills. Teachers should therefore use them more often. The initial test showed that many sixth graders had difficulty understanding newspaper text. However, newspapers are a good source of information that every citizen needs in order to be able to keep abreast of the times. The Finnish Newspapers Association has created an Internet site called 'Newspapers in Education' (http://www.sanomalehdet.fi/index.phtml?s=188). It provides material for teachers and shows how they can use newspapers when teaching students from different age groups. From 1994 onwards the Finnish Newspaper Association has arranged a newspaper week every year. It is a special week of cooperation between newspapers and schools. The newspapers supply schools and kindergartens with free copies of their publications for pupils and guide booklets for teachers. The idea is to provide all pupils with the opportunity to become familiar with newspapers.

The students who took part in the study have now moved from primary school to secondary school. There they need good reading comprehension skills to be able to acquire the information they need from various sources. We hope that their teachers have found ways to encourage even reluctant readers to read by using materials that the students find interesting. As was mentioned above, the most important activities during the intervention period were students' small group discussions. In groups it is easier to put together information from several idea units, to make inferences, and to 'read between the lines'. Explaining the meanings of words proved to be difficult for students in the sixth grade. According to Tomesen and Aarnoutse [17] students best gain knowledge of how to apply the strategies when they hear their teacher and peers think-aloud during the process. Therefore, discussing the meanings in groups may also have helped the students who could only explain 0-4 words in the initial test to learn the strategies needed for the word explanation process.

\section{References}

[1] Finnish National Core Curriculum for Basic Education, National Board of Education, Helsinki, 2004.

[2] R.M. Best, R.G. Floyd, and D.S. McNamara, "Differential competences contributing to children's comprehension of narrative and expository texts”, Reading Psychology, 29, 2008, pp. 137-164.

[3] J.P. Williams, K.M. Hall, K.D. Lauer, K.B. Stafford, L.A. DeSisto, and J.S. deCani, "Expositary text comprehension in the primary grade classroom”, Journal of Educational Psychology, 97, 2005, pp. 538-550.

[4] P. Bimmel and E. van Schooten, "The relationship between strategic reading activities and reading comprehension", L1 Educational Studies in Language and Literature, 4, 2004, pp. 85-102.

[5] P. Linnakylä and A. Malin, "Reading newspapers supports lifewide learning and active citizenship,” In P. Linnakylä \& I. Arffman, Eds., Finnish Reading Literacy. When quality and equity meet, University of Jyväskylä. Institute for Educational Research, 2007, pp. 231-248.

[6] J. Roiha, "Meriarkeologinen sensaatio 1600-luvulta. Ruotsalaistutkijat löysivät Itämerestä lähes ehjänä säilyneen hollantilaisaluksen." ["Sea-archaeological sensation. Swedish scientists found a well-preserved Dutch ship from the 17th century in the bottom of the Baltic Sea"], Turun Sanomat 16.11.2007, p. 6 .

[7] W.G. Brozo, To Be a Boy, to Be a Reader. Engaging Teen and Preteen Boys in Active Literacy. International Reading Association. Newark, 2002.

[8] T. Merisuo-Storm, 2006. "Girls and boys like to read and write different texts”, Scandinavian Journal of Educational Research, 50, 2006, pp. 111-125.

[9] D.R. Reutzel, J.A. Smith, and P.S. Fawson, "An evaluation of two approaches for teaching reading comprehension strategies in the primary years using science information texts", Early Childhood Research Quarterly, 20, 2005, pp. 276-305.

[10] M.H. Thompson. Transforming classroom instruction to improve the comprehension of fictional texts. In C. Collins Black \& S.R. Parris, Eds., Comprehension Instruction. Research-Based Best Practices. The Guilford Press, New York, NY, 2008, pp. 159-170.

[11] M. Parker and J. Hurry, "Teachers' use of questioning and modelling comprehension skills in primary classrooms", Educational Review, 59, 2007, pp. 299-314. 
[12] K. Cain, J. Oakhill, and K. Lemmon, "Individual differences in the inference of word meanings from context: The influence of reading comprehension, vocabulary knowledge, and memory capacity”, Journal of Educational Psychology, 96, 2004, pp. 671-681.

[13] H.L. Diehl, Snapshots of our journey to thoughtful literacy. The Reading Teacher, 59 (1), 2005, 56-69.

[14] N.K. Duke and N.M. Martin, "Comprehension instruction in action", In C.C. Block and S.R. Parris, Eds., Comprehension Instruction, Research-Based Best Practices. Guilford Press, New York, 2008, pp. 241-257.

[15] R.G. Fukkink, Deriving word meaning from written context: a process analysis. Learning and Instruction, 15 (1), 2005, pp. 23-43.

[16] K. Cain, "Deriving word meanings from context: does explanation facilitate contextual analysis?” Journal of Research in Reading, 30, 2007, pp. 347-359.

[17] M. Tomesen and C. Aarnoutse, Effect of an instructional programme for deriving word meanings. Educational Studies, 24 (1), 1998, pp. 107-128.

[18] M. van Daalen-Kapteijns, M. Elshout-Mohr, and K. de Glopper, "Deriving the meaning of unknown words from multiple contexts”, Language Learning, 51 (1), 2001, pp. 145181.

[19] A. Biemiller, "Vocabulary: Needed if more children are to read well." Reading Psychology, 24 (3/4), 2003, 323-335.

[20] C. Snow, A.P., Sweet, D.E. Alvermann, M.L. Kamil, and D.S. Stricland, "Formulating a research agenda about reading for understanding", In A.M. Roller Ed. Comprehensive Reading Instruction Across the Grade Levels. A collection of papers from the Reading Research 2001 Conference. International Reading Association, Newark, DE, pp. 88-110. 